\title{
¿Cese definitivo de la actividad armada o fin del terror? La declaración del fin de la violencia de ETA en la portada de los diarios españoles
}

\author{
Ainara Miguel SÁEz de URABAin \\ Universidad del País Vasco UPV/EHU \\ ainara.miguel@ehu.es \\ Miguel Ángel Moreno GALlo \\ Universidad de Burgos \\ mamgallo@ubu.es
}

Recibido: 4 de septiembre de 2014

Aceptado: 20 de enero de 2015

\begin{abstract}
Resumen
Este trabajo propone analizar la noticia del anuncio de ETA del fin de la violencia en la portada de los diarios de información general publicados en España el 21 de octubre de 2011, al día siguiente de que la banda enviara su comunicado a los diarios vascos Gara y Berria, la BBC y el The New York Times. Se trata de la interpretación global de 112 portadas, con el objetivo de conocer cuántas versiones diferentes del mismo hecho salieron a la luz aquel día, describirlas, y comprobar cómo los diferentes modos de tratar un mismo hecho noticiable construyen diferentes realidades que responden a un modo particular de ver el mundo: la ideología del medio y también, implícitas, la del grupo editor, el gobierno, la oposición, los anunciantes, los grupos de presión, etc.
\end{abstract}

Palabras clave: Violencia, ETA, portadas, periódicos, españoles.

\section{Final cessation of the armed activity or the end of terror? The declaration of the end of ETA's violence on the cover of Spanish newspapers}

\begin{abstract}
This paper aims to analyze the announcement of the end of ETA violence on the cover of general newspapers published in Spain on October 21, 2011, the day after the band sent their statement to the Basque daily Gara and Berria, the BBC and The New York Times. It is the overall interpretation of 112 covers, in order to know how many different versions of the same fact came to light that day, and to describe and see how the different ways of addressing the same newsworthy event build different realities related to a particular way of seeing the world: the ideology of the media and also, implicit, the ideology of the publishing group, the government, the opposition, advertisers, lobbyists, etc.

Keywords: Violence, ETA, covers, newspapers, Spanish.

\section{Referencia normalizada}

MIGUEL SÁEZ DE URABAIN, Ainara y MORENO GALLO, Miguel Ángel (2015): “¿Cese definitivo de la actividad armada o fin del terror? La declaración del fin de la violencia de ETA en la portada de los diarios españoles". Estudios sobre el Mensaje Periodístico. Vol. 21, Núm. 2 (julio-diciembre), págs.: 1111-1128. Madrid, Servicio de Publicaciones de la Universidad Complutense.

Sumario: 1. Introducción. 2. Objetivos. 3. Metodología. 4. Análisis; 4.1. Los datos formales; 4.1.1. Análisis de superficies; 4.1.2. Análisis de titulares, cuerpos e imágenes; 4.1.3. Colores y recursos; 4.1.4. Tipografía; 4.2. Los datos de contenido; 4.2.1. Análisis de titulares y cuerpos; 4.2.1.1. Los temas; 4.2.1.2. Las palabras; 4.2.2. Análisis de imágenes. 5. Conclusión. 6. Referencias bibliográficas. 7. Anexos: imágenes de 15 de las portadas de diarios españoles más significativas.
\end{abstract}




\section{Introducción}

El presente proyecto propone analizar la noticia del anuncio de ETA del fin de la violencia en la portada de los diarios de información general publicados en España el 21 de octubre de 2011, al día siguiente de que la banda enviara su comunicado a los diarios vascos Gara y Berria, la cadena pública británica BBC y el periódico estadounidense The New York Times. Se trata, pues, de comparar la presentación y la semantización de un determinado acontecimiento en más de cien diarios de un mismo día; un estudio sincrónico.

El análisis es exhaustivo, cuantitativo y cualitativo a la vez. Cuantitativo porque el número de portadas estudiadas asciende a 112, de modo que no queda más remedio que contar. Contar los milímetros de textos, imágenes y titulares, y la frecuencia de palabras, asociaciones de palabras, temas y silencios, como paso previo a un análisis de contenido de índole más valorativa.

Para analizar la forma y el contenido de las noticias se utilizará la semiótica textual. La configuración visual de la página es importante, porque sugiere la jerarquía (a través del peso visual) y el impacto (a través de su estética) de la noticia; refleja su relevancia. Sin embargo, aunque el diseño jerarquice, no significa nada más allá del contexto concreto. Por eso, un análisis de contenido resulta indispensable. Habrá que preguntarse, entonces, qué dice cada diario sobre el anuncio de ETA del fin de las acciones armadas, qué no dice y, evidentemente, cómo dice lo que dice: el punto de vista, el tono, las inferencias y presuposiciones, el valor de las palabras (y de las asociaciones de palabras) elegidas, las hipérboles y metáforas utilizadas, los mecanismos enunciativos, las relaciones intertextuales que promueve, etc.

Todo esto nos llevará a leer el mismo hecho de modos diferentes, tantos como ideologías implícitas propaga la prensa española cada día, y a comprobar, una vez más, que la tan cacareada objetividad de la información no es más que una evidente utopía.

Está claro que, a la hora de abordar el análisis, deberemos tener en cuenta que el origen de la noticia es otro texto, la Declaración de ETA, el comunicado que ETA envía a los medios con el propósito de "dar a conocer su decisión" de cesar para siempre "su actividad armada". Estamos, pues, trabajando con las diferentes interpretaciones (hipertextos) de un texto original, que también tendrá que estudiarse. ¿Por qué no tratar de responder, además, si el anuncio de ETAmerece la confianza del diario en cuestión?, ¿por qué no tratar de saber si el comunicado, para el diario que lo publica, corresponde a la verdad, a la falsedad, al secreto o al engaño?

\section{Objetivos}

El principal objetivo de esta interpretación global de las 112 portadas de periódico imprimidas el 21 de octubre de 2011 es conocer cuántas versiones diferentes de un mismo hecho salieron a la luz aquel día, describirlas, y comprobar cómo los diferentes modos de tratar un mismo hecho noticiable construyen diferentes realidades que responden a un modo particular de ver el mundo: la ideología del medio y también, implícitas, la del grupo editor, el gobierno, la oposición, los anunciantes, los grupos de presión, etc. 
Existen, además, otros objetivos más específicos, como comparar los distintos modos de contar la noticia en los diferentes diarios del País Vasco y ver, después, cómo se cuenta en las cabeceras cuya redacción no está tan cerca de los orígenes del conflicto.

\section{Metodología}

A la hora de enfrentarnos a esta larga lista de portadas de periódico, lo primero es poner orden. Para ello, proponemos un análisis textual en el que se tendrán en cuenta tanto la noticia como el diario en que se inserta.

El diario en que se inserta la noticia es muy significativo, porque cada una de las noticias analizadas está situada en la primera plana de un diario distinto, bajo un membrete que la enmarca tanto literal como metafóricamente. De acuerdo con los objetivos, se tendrán en cuenta, especialmente, si el diario es local, regional o nacional; su principal zona de difusión; su tirada, y el grupo editor al que pertenece.

En cuanto a la noticia, interesan sus datos de forma y contenido. Los datos formales dotan de relevancia informativa a los textos. Es preciso tener en cuenta que tanto el diario en el que se inserta la noticia como su forma orientan, guían (y, por ello, restringen) la interpretación del texto. Consideramos datos formales:

- El formato: la superficie impresa total, la superficie total de la noticia y las superficies de titular, texto e imágenes. También la ubicación de la noticia en la portada y la combinación de colores.

- La tipografía y el diseño gráfico: el tamaño y grosor de las letras, el tipo de letra, el uso de la mayúscula o la minúscula, la negrita, la cursiva, los subrayados.

- La cantidad y el tipo de imágenes.

Será preciso abordar, asimismo, los datos de contenido, el contenido latente de los mensajes, su significado, su sentido, y encontrar las claves para su interpretación. Responder a las preguntas: ¿qué ha pasado?, ¿qué se dice de lo que ha pasado?, ¿qué no se dice?, ¿cómo se dice lo que se dice?

Otra cuestión es la evidente necesidad de dividir la noticia en tres partes y estudiar en primer lugar el titular de la noticia, después el cuerpo y, por último, las imágenes. Aun así, no podemos olvidar que la noticia dividida (junto con los datos formales arriba mencionados) constituye un texto en sí mismo, un todo coherente, cuyo significado global va mucho más allá de la suma de las significaciones de las partes que lo componen.

Recurriremos, en este punto, al concepto de marco. Tanto el psicólogo Gregory Bateson como el sociólogo Erving Goffman están de acuerdo en que lo que hace el marco no es otra cosa que "definir la situación", a saber, encuadrar la realidad desde un determinado punto de vista. Del mismo modo que el diario enmarca el texto, la noticia enmarca las frases, las palabras y las imágenes. El diario es el marco en función del cual se atribuirá un significado al texto y se le asignará coherencia; igual que la noticia es el ámbito dentro del cual las frases, las palabras y las imágenes pierden su ambigüedad. 
En nuestro caso, todos los diarios analizados comparten tema (el anuncio de ETA), y tiempo comunicativo (20 de octubre de 2011), pero tanto el espacio como el enfoque es diferente en cada caso.

En cuanto al primero, es preciso aclarar que el espacio e incluso la idea del espacio es diferente para unos y otros. Habrá que tener en cuenta, entonces, quién escribe, desde dónde escribe (España, el Estado español, Euskal Herria, País Vasco, Euskadi, la Comunidad Autónoma Vasca, Iparralde...) y para quienes escribe. Porque cada diario, en orden a sus valores, toma una posición pública y crea un terreno sociocultural en el que sus "nosotros" y sus "ellos" no tienen por qué coincidir con los de los demás.

$\mathrm{Y}$ ahora es cuando las palabras encuadre, perspectiva, punto de vista o enfoque, todas ellas metáforas visuales, adquieren su sentido más amplio. Porque, según Gaye Tuchman, "la noticia es una ventana al mundo. Pero la vista desde una ventana depende de si ésta es grande o pequeña, de si su cristal es claro u opaco, de si da a la calle o a un patio" (Tuchman, 1978:1). Y es que una cosa es la historia, el tema de la noticia y otra, muy distinta, su tratamiento informativo. Una cosa es lo que se cuenta y otra, muy distinta, cómo se cuenta. En el tratamiento periodístico, en ese cómo, influyen muchos, muchísimos factores, no en vano la redacción de una noticia es el resultado de un proceso de mediación. Así, el periodista no cuenta, no puede contar, la realidad (¿qué es la realidad?, ¿existe realmente?), lo único que puede hacer es organizarla, transformarla en producto informativo. Y en ese proceso de transformación intervienen todas esas fuerzas que el profesor Stephen Reese (Shoemaker and Reese, 1996) ordenó en su jerarquía de influencias, a saber, la personalidad del periodista, sus actitudes, su preparación y experiencia; las rutinas de producción; la organización del medio; los gobiernos, anunciantes, fuentes de información, grupos de presión, otros medios... y la ideología.

Todas estas fuerzas son las que acaban de dar forma a los mensajes de los distintos medios de comunicación, las que hacen que el relato informativo se traslade al lector desde un determinado encuadre, una determinada manera de ver el mundo. Encuadrar la noticia significa tratar la información, elaborarla, seleccionando unos aspectos y excluyendo otros, destacando unos y ocultando otros. A continuación, veremos cómo encuadran cada uno de los 112 diarios estudiados la noticia del fin de ETA.

\section{Análisis}

\subsection{Los datos formales}

La disposición y relevancia de los elementos en la portada -tipografía, imágenes, espacios en blanco- no son ingenuos (Montero, 1999), porque también se relacionan con el tratamiento periodístico. En este caso, aunque no se trata de diarios comparables (Kaiser, 1982), puede intentarse una "contabilidad de superficies" (Núñez-Romero, 2009: 27) mediante la fragmentación en porcentajes (de la mancha, excluyendo los márgenes) de los titulares, imágenes y textos, considerando también el número de columnas, la cabecera y la tipografía en sus distintos elementos (normal o negrita, mayúsculas o minúsculas, tamaño...), como aproximación al significante de Barthes (1974). 
Aunque un análisis de la tipografía de todos los periódicos españoles permitiría tener una mejor referencia a la hora de establecer comparaciones entre ellos, los diferentes estudios, como el de Olmo y Parratt (2011) nos remiten al mayoritario uso de 5 columnas para los diarios de pago (frente a las 6 columnas de los gratuitos) y al formato tabloide, salvo excepciones. La tipografía depende de los libros de estilo de cada publicación, aunque la Romana suele ser la predominante, a veces combinada con otras familias de palo seco. El tamaño de los títulos también depende de las normas (tamaño más grande cuanto mayor es el número de columnas), aunque suele oscilar entre el cuerpo 12-18 para titulares a una columna, hasta el 40-64 para los de 5 columnas. En general se usa la alineación izquierda y el track negativo, si bien hay bastantes periódicos que utilizan la alineación centrada cuando la ocasión lo requiere.

Cabe significar, al efecto de interpretar los datos de este trabajo, que los periódicos analizados son 112, pero varios comparten portada. Así, El Periódico de Cataluña es matriz de Córdoba, El Periódico de Aragón, El Periódico de Extremadura y Mediterráneo de Castellón. Diario de Cádiz tiene la misma portada que Diario de Sevilla, Diario de Jerez, El Día de Córdoba, Europa Sur, Granada Hoy, Huelva Información y Málaga Hoy. Ideal de Granada da lugar a Ideal de Almería e Ideal de Jaén. La Opinión de Málaga es igual a La Opinión de Murcia. La Voz de Asturias usaba la portada de Público. El Mundo da lugar a las portadas de Diario de Soria y Diario de Valladolid. Otros periódicos (el grupo Promecal, con cabeceras en Castilla y León y Castilla La Mancha, o los Diarios de Noticias de Álava, Guipúzcoa y Navarra, por ejemplo) dejan libertad de elección para las ediciones locales, por lo que sí se han considerado individualmente en este trabajo.

\subsubsection{Análisis de superficies}

La noticia del cese de la actividad terrorista de ETA ocupó espacios destacados en los medios de comunicación españoles, prensa incluida. Prácticamente todos los periódicos la llevaron a la cabecera, si bien en seis casos (El Telegrama de Melilla, El Pueblo de Albacete, Diario de Teruel, El Faro de Ceuta, Melilla Hoy y Menorca) se optó por publicarla en espacios inferiores. Como se puede ver por la selección de cabeceras, los periódicos de las ciudades africanas, la isla de Menorca y lugares del interior como Teruel y Albacete, recibieron la noticia con relativo interés.

Si contamos el número de columnas que ocupó la noticia, la media es de 4,78 (sobre cinco columnas teóricas de todos los periódicos), una cifra realmente elevada. La inmensa mayoría, prácticamente todos los que ocupan la cabecera, usan las cinco columnas, pero de nuevo hay excepciones: El Telegrama de Melilla, ni la cita; El Ideal Gallego le dedica una columna; Menorca se conforma con dos columnas (y no está en la cabecera). Otros nueve periódicos (Nueva Alcarria, El Pueblo de Albacete, El Día de Cuenca, La Tribuna de Toledo, Expansión, El Faro de Ceuta, Melilla Hoy, Diario de Avila y Diario de Almería) llevan la noticia a la cabecera, pero la dejan en cuatro columnas.

En cuanto a la superficie total de la portada que ocupa la noticia de ETA, la media es del 44,14\%. Los valores mínimos, como cabía esperar, son el 0,0\% de El Telegrama de Melilla; 3,4\% de El Ideal Gallego (en cabecera, pero a una columna); 6,2\% de $\mathrm{Me}$ - 
norca (a dos columnas, sin cabecera); 8,8\% de Diari Mes Tarragona (en cabecera a cinco columnas); $8,9 \%$ de La Provincia de Las Palmas (cabecera a cinco columnas); $12,0 \%$ de El Pueblo de Ceuta (en cabecera y a cinco columnas, pero en realidad de pequeño tamaño respecto al conjunto); y 12,7\% de Nueva Alcarria (en cabecera a cuatro columnas). De nuevo se observa una peculiar distribución geográfica periférica al País Vasco. A cambio hay varios periódicos que ocupan toda la portada con la noticia: Ara Barcelona, Las Provincias de Valencia, e Ideal de Granada. Por encima del 80\% de la superficie de la portada se encuentran El Correo de Vizcaya, Sur de Málaga, Diario de Burgos, El Punt-Avui de Barcelona, Deia de Vizcaya, Diario de Noticias de Navarra, Noticias de Guipúzcoa y Diario de Noticias de Álava. ABC, El Correo de Andalucía y El Diario Vasco dedican más del 77\% de la portada. La distribución geográfica es asimismo significativa, con presencia de los periódicos vascos, catalanes y algunos andaluces, entre otros. Hay tres casos extremos: Público, La Razón y Gara, que dedican la portada completa y también la última página (en realidad el $200 \%$ de la superficie de la portada) en un desplegable conjunto.

\subsubsection{Análisis de titulares, cuerpos e imágenes}

Los titulares de la noticia ocupan una media del $22,18 \%$ de la mancha de la portada (excluyendo los márgenes). El más grande es el de Deia, con un $83,1 \%$. También tienen un considerable tamaño El Correo de Vizcaya (80,10\%), El Diario Montañés (64,4\%), El Correo de Andalucía (60,5\%) y Las Provincias (60,1\%). Son significativamente pequeños El Ideal Gallego (1,3\%), Melilla Hoy (1,5\%), Diario Noticias de Álava (3,2\%, aunque con una enorme imagen), Menorca (5,0\%), Berria (6,1\% con una imagen grande que ocupa el $40 \%$ ) y Noticias de Guipúzcoa (7,8\%, también con una gran ilustración).

La imagen que compaña a la información ocupa un promedio del 19,88\% de las portadas de la prensa española de aquel día. Pero hay que tener en cuenta que a veces no hay fotografía, sino un dibujo o anagrama; que en otras ocasiones la fotografía es el fondo para el titular y el texto, y que la maquetación puede también dar preferencia a espacios en blanco, sin imágenes, para resaltar los titulares. Así, 37 periódicos no incluyen ninguna imagen, frente a dos que usan una ilustración del tamaño de la portada y uno (La Razón), que despliega la imagen de la portada incluso hasta la última página).

El texto que acompaña a los titulares es muy pequeño (una media del $2,77 \%$ de la portada), apenas unas líneas resumiendo la noticia y remitiendo al interior. Cincuenta y cinco periódicos no tienen ningún texto, frente a Gara que dedica un 36,9\% de la portada (y buena parte de la última página) a desarrollar la noticia. Asimismo le dedican más de un 10\% de la portada La Gaceta (16,0\%), Berria (13,8\%), La Gaceta Regional de Salamanca (13,8\%), La Razón (12,3\%) y El País (10,8\%).

\subsubsection{Colores y recursos}

Los periódicos que pretenden dar una imagen de formalidad suelen prescindir del color como recurso tipográfico, mientras que otros, más populares, usan la combinación de colores, las tramas o los negativos con cierta profusión en sus ediciones dia- 
rias. Por eso, el análisis del grafismo de gamas y tonalidades tiene una significación relativa. La mayoría de los 94 diarios analizados no hacen un uso específico del color, mientras que usan el rojo en el titular (normalmente antetítulo y subtítulo y a veces parte del título) El Correo, Ideal de Granada, La Opinión de Murcia, Público, Levante, El Correo Gallego, El Periódico, Diari de Tarragona, La Voz de Cádiz y El Punt-Avui. Usan negativos El Correo, Segre, DBalears, Última Hora de Mallorca y Bondia. Hay también un uso singular del color en algunos casos: fondo en gris y blanco en Las Provincias; fondo gris en Melilla hoy; fondo rojo claro y letras azules en El Faro de Ceuta; ETA en amarillo en DBalears; sumario con fondo azul claro en La Verdad de Murcia; fondo azul en una parte de Berria; foto enmarcada en negro en Diari de Tarragona.

Gráficamente, son espectaculares las primeras páginas de Deia (la palabra Bakean ocupando tres líneas de enorme tamaño, con una sílaba en cada línea); Diario de Noticias de Álava, con una portada en blanco y la palabra FIN flotando en el medio; Noticias de Guipúzcoa, muy parecida a la anterior, con las palabras POR FIN; y los periódicos del grupo Ideal con un enorme sello en el que se ha sustituido el anagrama de ETA por la palabra FIN.

\subsubsection{Tipografía}

Las normas tipográficas de un buen número de periódicos señalan que en los titulares ha de usarse letra negrita. Es una cuestión no tanto de mancha como de equilibrio visual, porque si bien para el texto corriente, en cuerpos de 8 o 9 puntos Didot, ha de usarse una tipografía redonda que impida el empaste de serifa y ojos, en los titulares se puede imprimir una mayor superficie tipográfica sin que se produzca tal problema.

En las portadas consideradas en este trabajo se aprecia el uso de tipografía normal (normalmente negrita) en 28 titulares $(30,1 \%)$, mientras en los 65 restantes $(69,9 \%)$ se ha optado por una mancha superlativa de los tipos.

El uso de los titulares en mayúsculas suele estar restringido en los periódicos que pretenden ofrecer una imagen de seriedad, no sólo por cumplir con las normas de la Real Academia, sino también para evitar la imagen de grito que se ha convertido casi en un protocolo de Internet. Pero los diarios más populares continúan haciendo uso de este socorrido recurso (recordemos que en la antigüedad clásica las mayúsculas eran símbolo de formalidad frente a las minúsculas) simplemente para incrementar la mancha de los titulares. En el caso de la noticia de ETA, hay que considerar que el propio nombre de la banda es una sigla y se escribe con mayúsculas, lo que permite ciertas licencias tipográficas, por ejemplo junto a la palabra FIN. De los 94 periódicos considerados, $16(17,2 \%)$ usan las mayúsculas, normalmente en títulos breves: FIN (El Diario Vasco); BAKEAN (Deia); POR FIN (Diario de Noticias de Navarra, Noticias de Guipúzcoa y Diari de Tarragona); AGUR ETA (Público). Otros insertan algunos títulos más largos: ADÉU A LES ARMES (Ara); ETA RENUNCIAA LAS ARMAS (Canarias 7), ETA SE RINDE (Diario de León); LA DEMOCRACIA DERROTAA ETA (El Correo de Andalucía); ETA declara la PAU (El Punt-Avui); ETA NOS DEJA EN PAZ (Ideal); ETA ABANDONA EL TERROR (La Provincia); ETA DEJA LAS ARMAS (La Tribuna de Ciudad Real); ETA, ADIÓS A LAS ARMAS (Segre). 
En cuanto al tamaño de la tipografía, 55 periódicos usan un tamaño normal, estándar, para las cinco (o cuatro columnas) de la noticia, frente a 28 que emplean titulares que podríamos llamar grandes, y 7 que utilizan cuerpos muy grandes. Deia ocupa toda la portada con seis letras -BAKEAN- en tres líneas. También es de gran tamaño la palabra FIN de El Diario Vasco. Además de estos dos periódicos vascos, El Correo y Noticias de Guipúzcoa usan cuerpos de gran tamaño. Otros periódicos con gran tipografía son Diari de Tarragona, El Punt-Avui y Sur de Málaga. Como puede apreciarse, cuatro de los diarios que usan recursos tipográficos excepcionales son vascos y dos catalanes. También en el uso de mayúsculas destacaban los mismos cuatro periódicos de Euskadi y los dos de Cataluña, a los que habría que sumar Segre.

Por el contrario, usan tipografía pequeña (para lo que sería normal en una noticia de estas características) El Faro de Ceuta, que da mayor realce, incluso con mayúsculas, a una noticia local, y Melilla Hoy, que se limita a poner un pequeño título al pie de foto. Es muy pequeño el titular de El Ideal Gallego, a una columna y con un tamaño de sumario.

\subsection{Los datos de contenido}

\subsubsection{Análisis de titulares y cuerpos}

\subsubsection{Los temas}

La organización textual y discursiva de las noticias responde a la pirámide invertida, por lo que entendemos que lo que cada diario escribe en su titular es el tema principal de la noticia. Como ya hemos indicado, el hecho noticioso corresponde al envío por parte de ETA de un comunicado en el que se declara, literalmente, "el cese definitivo de su actividad armada". Esta declaración, que en el documento está precedida por seis párrafos, es la que prácticamente todos los titulares coinciden en destacar, sólo que no lo hacen de la misma forma.

De los 111 títulos estudiados (El Telegrama de Melilla no saca la noticia en portada), 33 (29,7\%) citan abierta aunque indirectamente el comunicado y todos ellos utilizan el verbo "anunciar", excepto dos: El Día de Valladolid, que respeta el verbo utilizado en el comunicado (declarar) y Expansión, cuya elección "ETA dice que deja de matar..." resta seriedad al anuncio. El resto de los títulos, 78 (70,3\%), no citan el comunicado y, en vez de informar sobre el anuncio del fin de ETA, informan sobre el fin en sí mismo.

No todos los títulos, sin embargo, coinciden en dar esta información y son muy pocos los que se resisten a publicar su propia interpretación del comunicado. Únicamente 21 dicen que ETA anuncia su fin y 13 más hablan directamente del fin de ETA; $34(30,6 \%)$ títulos de 111. Los demás interpretan. Unos, los más, escriben que ETA deja las armas (22) o que anuncia que deja las armas (4), 10 hablan de rendición ("ETA claudica" o "ETA se rinde"), 6 de paz ("Bakean", "ETA declara la PAU", "ETA nos deja en paz"), 5 de despedida ("Adéu a les armes", "ETA, adiós a las armas, "20 de octubre de 2011 AGUR, ETA", "ETA, hasta nunca"), 3 de derrota ("La democracia derrota a ETA" o "ETA acepta su derrota") y 1 de futuro ("Un nuevo tiempo para Euskal Herria"). Pero otros, los menos, advierten en el mismo título de que "ETA deja la violencia, pero no se disuelve" (16), "ETA deja la violencia, pero no entrega las armas" 
(3) o "ETA ni se disuelve ni entrega las armas" (3). Dos (2) títulos se desmarcan subrayando las reacciones de los partidos al anuncio y otros dos (2) resultan inclasificables ("ETA alardea de sus asesinatos y emplaza al Gobierno a negociar").

Vistos los números, entendemos que algunos de los títulos merecen párrafo aparte por lo explícito de su interpretación. Es el caso del único título en hablar de futuro y también, por qué no decirlo, de Euskal Herria. Se trata del título del diario Gara: "Un nuevo tiempo para Euskal Herria", que recoge las primeras palabras del tercer párrafo del comunicado ("En Euskal Herria se está abriendo un nuevo tiempo político"). Gara es el diario que más profusamente cita el comunicado y el único de los estudiados, junto con Berria (cuyo titular es bastante neutro "ETA armak utzi ditu" ), que recibió la información directamente de la organización. Otros títulos dignos de mención son los de los diarios $A B C$ y La Gaceta. Para el primero, "ETA ni se disuelve ni entrega las armas"; para el segundo, "Mil asesinatos después, ETAni se disuelve ni entrega las armas". Cabría preguntarse, entonces, cuál es la noticia que merece estar en portada. También El Mundo publica un título explícitamente interpretativo: "ETAalardea de sus asesinatos y emplaza al Gobierno a negociar". La toma de postura de estos diarios con respecto al hecho noticiable está más que clara desde el mismo titular. Y son precisamente ellos, Gara, $A B C$ y El Mundo, los que reflejan los puntos de vista más extremos.

Porque, aunque parezca increíble, a la luz de los títulos se reflejan ya las tres perspectivas que harán que la información varíe tanto que parezca que las noticias traten de distinto tema. $\mathrm{Y}$ es que, según se destaquen unos u otros aspectos, la noticia pasa de anunciar el fin de ETA o no hacerlo en absoluto. Así, mientras que para la mayoría de los diarios ETA deja las armas y, para otros, ETA deja las armas pero no se disuelve, hay unos pocos para quienes ETA no hace ni una cosa ni la otra. Fijándonos tan solo en el título, son $85(76,6 \%)$ los diarios que afirman que ETA deja las armas, $22(19,8 \%)$ los que dicen sí pero no y $3(2,7 \%)$ los que dicen no. Y estos tres son, exceptuando Gara, los arriba comentados: ABC, La Gaceta y El Mundo.

No obstante, los números cambian a medida que avanzamos en la lectura. Si, en vez del título, tenemos en cuenta el cuerpo de las noticias, veremos que sólo 65 $(58,6 \%)$ de los periódicos analizados informan del fin de ETA. Los otros veinte que en el título parecían creer el anuncio de la organización, no dejan de exponer sus dudas a continuación, por lo que se eleva a $45(40,5 \%)$ el número de diarios que mantienen sus reservas ante el comunicado.

Así, para 65 de los diarios analizados, el anuncio de ETA corresponde a la verdad pero, para otros 45 , es un engaño. ¿Qué periódicos son esos que se permiten interpretar la información de un modo tan explícito? Como la lista es larga, diremos que entre ellos están la mitad de los periódicos nacionales, 4 de 8 ( $A B C$, Expansión, La Gaceta y La Razón), y casi la mitad de los periódicos de mayor tirada, 3 de los 8 que superan los 100.000 ejemplares (ABC, La Razón, La Voz de Galicia), pero sólo 1 de los 9 diarios editados en el País Vasco y Navarra (Diario de Noticias de Álava). Curiosa-

${ }^{1}$ ETA deja las armas, en euskera. 
mente, del mismo modo que la mitad de los periódicos nacionales, aproximadamente la mitad de los diarios provinciales (41 de 69) y locales ( 8 de 17) juzgan verdaderas las palabras de ETA. La proporción de diarios regionales es inferior (4 de 16). Teniendo en cuenta los grupos editoriales, resulta interesante que de los 9 diarios del grupo Joly todos consideren el anuncio un engaño, al igual que 6 de los 13 del grupo Moll, 4 de los 7 de Promecal, 3 de los 15 de Vocento y 1 de los 2 de Unidad Editorial.

\subsubsection{Las palabras}

La palabra "ETA" es, lógicamente, la más repetida en los titulares. Aparece en cien de los 111 titulares y las excepciones son significativas por su elipticidad. No aludiendo a ETA, el periódico ya está diciendo mucho; lo más importante, que supone la existencia de un lector competente y bien informado que sabrá rellenar el vacío del texto e interpretar su significado. Por eso, no es raro que de los 11 diarios que no utilizan la palabra ETA 6 sean vascos y 2 catalanes; por orden alfabético: Ara ("Adéu a les armes"), Deia ("BAKEAN"), Diari de Tarragona ("POR FIN"), Diario de Avisos ("Claro, firme y definitivo"), Diario de Noticias ("POR FIN"), Diario de Soria ("Soria celebra el anuncio aunque el PP espera su disolución y el PSOE que sea definitivo"), Diario de Noticias de Álava ("FIN (o casi)"), El Diario Vasco ("FIN"), El País ("El fin del terror"), Gara ("Un nuevo tiempo para Euskal Herria") y Noticias de Gipuzkoa ("POR FIN").

Otras palabras destacadas en titulares son "armas" y "violencia". La primera aparece en 28 titulares ( 23 en castellano, 4 en catalán y 1 en euskera), pero no en todos tiene el mismo sentido. El más habitual, el de que ETA deja las armas, aparece en 22 ocasiones. En otras 6, lo que se trata de decir es justo lo contrario, a saber, que en realidad ETA ni se disuelve ni entrega las armas; otra vez la misma paradoja. La segunda, "violencia", surge en 24 titulares, y siempre en el mismo sentido: ETA deja la violencia. Sólo en una ocasión está acompañada de un adjetivo, "terrorista", que no hace sino reforzar su sentido negativo: "ETA pone fin a 51 años de dolor y violencia terrorista", en El Correo Gallego.

"Armas y "violencia" resultan ser bastante neutrales si las comparamos con los titulares en que ETA abandona el "terrorismo" (8), el "terror" (5), las "pistolas" (1) y la "actividad terrorista" (1) o, simplemente, deja de "matar" (3). La primera, "terrorismo", es considerada por Eliseo Verón (1976) una palabra clave para la semantización de la violencia de masas. Frente a éstos, destacan los títulos que, recogiendo las palabras del comunicado, comunican que ETA abandona la "lucha armada" o la "actividad armada". Son 9 y sólo 2 utilizan comillas; entendemos, pues, que el resto hace suyas las palabras de la organización. La lista es sorprendente porque, en su mayoría, se trata de pequeños diarios provinciales publicados fuera del País Vasco: El Adelantado de Segovia, El Adelanto de Salamanca, El Día de Cuenca, La Crónica de León, La Tribuna de Toledo, Diario de Ávila y La Razón. Con todo, sólo El Adelanto de Salamanca, El Día de Cuenca y La Crónica de León se abstienen de mencionar la palabra "terrorismo" en el resto del titular, ya sea en el antetítulo o en los subtítulos.

Como la palabra "armas", también el término "paz" aparece en varias lenguas, 4 en castellano (el "ETA nos deja en paz" del Ideal, Ideal de Almería, Ideal de Jaén e 
Información), 1 en euskera (el "Bakean" de Deia) y otra en catalán ("ETA declara la PAU", en El Punt Avui). Pese a su lógica, no deja de ser curioso que, otra vez, los titulares más poéticos y esperanzadores sean vascos y catalanes.

Otro vocablo muy repetido es "fin". Sale 23 veces, la mayoría de ellas acompañado de las palabras "violencia", "terrorismo" o "terror" (el título del periódico de mayor tirada, El País, no es otro que "El fin del terror"). Lo más destacable, sin embargo, es que en 7 ocasiones aparece en solitario. En 5 de ellas, además, la palabra "fin" está en mayúsculas y lo es todo. Se trata de los titulares antes mencionados, aquellos que contaban con la complicidad del lector, los "POR FIN" del Diari de Tarragona, Diario de Noticias y Noticias de Gipuzkoa, el "FIN" de El Diario Vasco y el "FIN (o casi)" del Diario de Noticias de Álava.

Pero la palabra más reveladora es, quizá, el adjetivo "definitivo" que, pese a aparecer en 13 ocasiones, sólo en 4 significa lo que significa. Las otras 9 aparece entrecomillada lo que, por un lado, expresa que se trata de una cita literal (las citas abiertas directas siempre parecen aportar objetividad al enunciado) mientras, por otro, deja patente que la voz del diario no coincide con la de ETA. Y está claro que cuando la voz del autor no coincide con la voz convocada, asoma la ironía...

En el caso del periodismo, es importante crear efecto de objetividad (otra cosa es que este efecto se corresponda con una objetividad real), por lo que la persona que escribe debería permanecer ausente. Pero las comillas, igual que los signos de exclamación, los recursos estilísticos y los peros (ETA deja la violencia "pero no se disuelve" o "pero no entrega las armas"), sirven también para introducir las actitudes y la perspectiva del periodista en el enunciado. Si bien, dado que estamos ante textos periodísticos, la función del lenguaje predominante debería ser la referencial, es evidente que en muchos titulares dominan las funciones expresiva y apelativa. La importancia del destinador, por ejemplo, se subraya en los expresivos títulos "POR FIN" (Diari de Tarragona, Diario de Noticias, Noticias de Gipuzkoa), "FIN" (El Diario Vasco), "FIN (o casi)" (Diario de Noticias de Álava), "Se acabó ETA" (Alerta), "BAKEAN" (Deia), "AGUR, ETA" (La Voz de Asturias, Público) y "ETA, hasta nunca" (La Crónica de Badajoz); mientras que la función apelativa, que apela al destinatario, está clara en el "ETA nos deja en paz" del Ideal.

Otros titulares, no muchos, utilizan procedimientos retóricos que parecieran indicar que el mensaje es más importante que aquello sobre lo que se habla, por lo que su función predominante sería la poética. Destacamos la hipérbole de El País ("El fin del terror"), las metáforas de El Faro de Ceuta, Ara y Segre ("ETA pone punto y final", "Adiós a las armas"), la personificación de La Rioja y El Correo de Andalucía ("La democracia derrota a ETA") y el doble sentido de los titulares del Deia ("BAKEAN", puesto que la palabra, tan grande que ocupa toda la portada, está escrita sobre los nombres de los muertos; tanto los muertos a manos de ETA como los muertos a manos de las fuerzas policiales) y el Ideal ("ETA nos deja en paz").

Hasta el momento hemos hablado sólo de titulares, pero en los textos de las noticias pueden leerse también diferentes palabras y asociaciones de palabras que las distintas cabeceras utilizan para expresar un mismo concepto. Prestaremos especial atención a aquellas cuya elección tiene más valor, aquellas que sirven para orientar la argumentación del 
texto en uno u otro sentido. Y es que, como veremos, no hay palabras inofensivas para hablar de ETA, porque la mayoría de ellas están involucradas en una extensa red de significaciones sociales que esconde dobles o triples sentidos. De ahí que al elegir entre, por ejemplo, las palabras "banda" u "organización” el periodista realice una operación ideológica. Igual que al combinar, por ejemplo, la palabra "conferencia" con el adjetivo "internacional" o, por el contrario, con el sustantivo "farsa".

Pues bien. A pesar de que ETA, en su comunicado, se denomina a sí misma “organización socialista revolucionaria vasca de liberación nacional”, 96 (85,7\%) portadas se refieren a ella como "banda" (una palabra que denota comportamiento agresivo y cierta parcialidad), "banda terrorista" (banda sí, y además terrorista), "organización terrorista" (organización sí, pero terrorista), "terroristas" o algo peor, "asesinos", según el Diario de Avila. Las 16 restantes se reparten entre las que la llaman “organización” a secas (Berria, Gara y Nueva Alcarria), las que escriben simplemente ETA (Diario de Navarra, Diario de Noticias, El Correo, Diario Vasco, DBalears, Diari de Girona, Diari de Tarragona, El Correo Gallego, El Pueblo de Ceuta) y las que son tan elípticas que ni siquiera la nombran (Deia, Diario de Noticias de Álava, Noticias de Gipuzkoa, Ara). Seguramente, algunas de estas 16 publicaciones hablarán de "banda" en su interior, pero aun así sigue siendo significativo que el listado esté compuesto de 9 portadas vascas (todas las que son), 4 catalanas y 1 gallega.

Otra combinación de palabras clave es la de "Conferencia Internacional", que es la que utiliza ETA para designar el evento celebrado en el palacio donostiarra de Ayete el 17 de octubre de 2011, justo tres días antes la declaración que nos ocupa y al que asistieron, entre otras personalidades, el Nobel de la Paz y exsecretario general de la ONU Kofi Annan y el presidente del Sinn Féin Gerry Adams. De los 21 diarios que mencionan el acontecimiento en cuestión, 9 lo llaman "reunión de San Sebastián" y otros 9 "conferencia". Los de la "reunión" son los diarios del sur, Los Diarios de Almería, Cádiz, Jerez y Sevilla; El Día de Córdoba, Europa Sur, Granada Hoy, Huelva Información y Málaga Hoy. Los de la "conferencia”, sin embargo, son mucho más variados. Y es que lo que para unos es una "Conferencia en San Sebastián” sin más (El País), una "Conferencia Internacional” (Berria, Diario de Ibiza e Información), o una "Conferencia de Paz" (El Correo Gallego, El Día de Cuenca, La Crónica de Badajoz, La Opinión de Málaga, Melilla Hoy y Nueva Alcarria), se convierte para otros en una "supuesta conferencia internacional" (La Gaceta Regional de Salamanca) o, aún peor, en una "conferencia-farsa" (La Gaceta). Igual de explícitamente interpretativo resulta el "cónclave de San Sebastián" de La Tribuna de Ciudad Real, que utiliza la palabra latina "cónclave" cuya significación, que se cierra con llave, sugiere secretos y recuerda a los cardenales de la Iglesia Católica eligiendo Papa. En otra línea, El Diario de Noticias y Gara hablan de la "Declaración de Aiete".

En este punto, es necesario detallar otro de los principales puntos de desencuentro, el número de personas que han perdido la vida a causa del conflicto que parece tocar a su fin. Al tratarse de cifras, la divergencia resulta más escandalosa todavía. Porque de las 61 portadas que mencionan el número de muertes, $29(47,5 \%)$ las cifran en 829 , $19(31,1 \%)$ en 858 (aunque La Opinión A Coruña, incluida aquí cuente uno menos), $7(11,5 \%)$ en más de 800 (Cinco Días, Diario de Teruel, El Día de Valladolid, El Día 
Santa Cruz de Tenerife, El Progreso, Expansión, Última Hora), 3 (4,9\%) en casi 900 (La Crónica de León, Las Provincias, Melilla Hoy) y 1 (1,6\%) en 1.000 (La Gaceta). Berria, por su parte, suma a los "más de 800 muertos causados por ETA, los aproximadamente cien miembros de la organización que han muerto en el mismo periodo"; algo parecido a lo que hace Deia, al escribir en su portada los nombres de los asesinados en ambos bandos.

Otras asociaciones de palabras que merecen detallarse son las hipérboles y las metáforas. De este modo, se ve claro que lo que para unos diarios es un "documento histórico" (Berria), un "anuncio histórico" (El Día de Valladolid) o "el anuncio más esperado de las últimas décadas de la historia de España" ( $L a$ Voz de Cádiz), no es para otros más que "un acto de teatro" (La Nueva España y La Opinión A Coruña). Y que, aunque algunos coincidan con los anteriores en señalar la trascendencia del hecho noticioso (no en vano El Correo habla de "un día para la historia" y El Diario Vasco de "un día para la esperanza"), lo cierto es que la mayoría de los procedimientos retóricos no hacen más que exacerbar el morbo. Véanse, si no, las siguientes metáforas: "medio siglo de sangre y duelo" (El Correo), "medio siglo de asesinatos y extorsiones" (El Diario Montañés), "negra huella" (Diario de Burgos), "negra trayectoria" (Heraldo de Soria), "trayectoria letal" (Heraldo de Aragón), "dictadura del terror" (Diario Palentino), "sangre sin arrepentimiento" (La Razón), "sangre derramada" (La Voz de Galicia), "baño de sangre" (La Voz de Cádiz) y "lacra sangrienta" (Segre).

\subsubsection{Análisis de imágenes}

ETA es también la gran antagonista de las imágenes. Al clasificar los diarios según el contenido de la fotografía que eligieron para su portada, nos encontramos otra vez con tres grandes grupos: aquellos que decidieron no acompañar la noticia de ninguna imagen (47, un 42,0\%), los que decidieron ilustrarla con imágenes icónicas (45, un $40,2 \%)$ y los que resolvieron utilizar imágenes simbólicas que aportaran significado $(20,17,9 \%)$.

De un total de 65 portadas con imágenes, 45 (69,2\%) son icónicas. De estas, 37 (el $56,9 \%$ del total) muestran un fotograma del vídeo enviado por ETA. El tamaño varía mucho y la imagen puede publicarse en color, a cinco columnas y en la parte superior de la página, o en blanco y negro, ocupando una o dos columnas en uno de sus márgenes. Pero el encuadre es casi siempre el mismo. Se trata del plano frontal de tres miembros de ETA sentados ante una mesa sobre la que se apoya un micrófono. Visten txapela, jersey y guantes negros, y ocultan su rostro bajo una especie de capucha blanca con agujeros para los ojos. Tras ellos, un fondo azul con el anagrama de la organización en el centro. A los lados, la ikurriña, la bandera de Navarra y el "arrano beltza", un águila negra símbolo de poder. En 23 de las 37 imágenes, los tres encapuchados alzan el puño, un gesto con el que acompañan el final de su declaración. Paradójicamente, pese a su iconicidad, la imagen contiene una gran cantidad de símbolos.

Icónicas son también las 3 portadas que, en vez de un fotograma del vídeo de ETA, muestran el mismísimo comunicado o, como en el caso de Berria, el comunicado junto al lápiz de memoria en el que se le ha hecho llegar la información. Mediante la reproducción de ambos elementos lo que este diario trata de destacar es, evidentemente, que 
sus informaciones son de primera mano. La razón por la que los otros dos periódicos, Diario de Noticias y El Punt Avui, han elegido representar el comunicado, sin embargo, no está tan clara. Sea cual sea, al mostrar el documento, estos tres diarios explicitan el acto comunicativo como momento de mediación y de reorganización de los datos, a saber, muestran el mostrar, frente a todos los demás que, decantándose por la forma más tradicional de comunicación, muestran el mundo como si no hubiera mediadores.

La mayoría de las 20 (30,8\%) portadas más simbólicas se dividen entre las que reproducen el sello de ETA tachado, resquebrajado o a punto de ser borrado (11) y las protagonizadas por dos o más huellas de manos blancas alzadas en rechazo de la violencia (7), pero hay dos que son diferentes al resto. Se trata de las de La Razón y Gara, diseñadas a modo de dípticos, puesto que la noticia ocupa ambas portadas y contraportadas. La Razón publica en su portada la típica fotografía de los tres encapuchados puño en alto; en la contraportada, sin embargo, vemos un primerísimo plano del rostro de Miguel Ángel Blanco sobre el que se han plasmado besos y escrito palabras solidarias. Gara, al contrario, imprime la fotografía más repetida (en esta ocasión sin puños alzados) en la parte superior de la contraportada, y reserva para la parte inferior de la portada y contraportada un cuadro que recuerda a El Guernica, una metáfora de las consecuencias de la opresión, pero también de la esperanza.

Pese a la originalidad de estas últimas, llama la atención la cantidad de imágenes repetidas. Muchos periódicos coinciden con su foto de portada. En algunos casos, la repetición responde al hecho de que varias cabeceras pertenezcan a un mismo grupo editor que, por cuestiones de rentabilidad, publica las mismas imágenes. En otros, las razones no están tan claras y se puede hablar de rutinas de producción y coincidencia en los criterios de selección. Lo cierto es que la repetición hace que la imagen se fije en la memoria del lector de modo que algunas imágenes, como la de los encapuchados de ETA y las manos blancas, ya formen parte del imaginario colectivo.

\section{Conclusión}

Retomemos, para terminar, la pregunta lanzada al principio de este trabajo: ¿podemos confiar en la objetividad de la prensa española? La respuesta es no, no podemos. Es cierto que nos hemos ocupado sólo de analizar las primeras planas sin tener en cuenta el interior, pero la representatividad y la importancia mediática de las portadas es indudable. Y las diferentes portadas de las ediciones impresas de la prensa nacional no coinciden ni en la relevancia concedida a la noticia, ni en su naturaleza, ni en su proyección.

De este modo, mientras que para unos diarios la noticia es tan importante que deciden dedicarle la totalidad de su portada y emplear ese día un diseño especial, poéticos titulares e imágenes simbólicas, para otros no merece más que una breve mención al margen. Mientras que para unos diarios ETA se ha acabado definitivamente, para otros se ha acabado a medias, y para unos pocos no se ha acabado. Y, al tiempo que unos diarios se proyectan en el futuro y envían mensajes de diálogo, paz y esperanza, otros siguen anclados en el pasado y hablando de atentados, asesinatos, muerte, sangre y amenazas.

Según el espacio que ocupa la notica, las palabras utilizadas, las declaraciones destacadas... la información varía tanto que parece que las noticias traten de distinto 
tema. Pero se trata del mismo tema, del mismo comunicado, enfocado eso sí desde tres puntos de vista diferentes. Así, lo que para unos periódicos es verdad y para otros una verdad a medias es, para unos pocos, un engaño.

$\mathrm{Si}$ atendemos a la identidad de las cabeceras, las conclusiones son sorprendentes. $\mathrm{O}$ no tanto. Porque coincide que los diarios que más importancia dan a la noticia, los que recurren a portadas espectaculares e imágenes simbólicas, creen que el anuncio de ETA es verdad, y proyectan su optimismo en el futuro en forma de esperanza, son diarios vascos, escritos en y para el País Vasco (Euskadi o Euskal Herria, dependiendo del medio). La cercanía geográfica es uno de los factores que intervienen a la hora de seleccionar y enfatizar una noticia, por lo que explica perfectamente la relevancia que los diarios vascos conceden a la noticia. Y también podría explicar su enfoque positivo, puesto que, cuanto más cerca esté uno del problema, antes quisiera creer en su solución.

Es evidente, además, que la mayor parte de las cabeceras toman postura y que, aunque algunas se queden en interpretaciones implícitas, abundan las valoraciones. Así, las rutinas periodísticas de citar las fuentes de información, hacerlo con precisión e incluir opiniones contrarias, no son suficientes para procurar un efecto de objetividad socavado, muchas veces, por el diseño, el enfoque o la simple elección de las palabras. Muchos de los diarios estudiados se muestran abiertamente sensacionalistas dedicados, en vez de a transmitir un acontecimiento, a mostrar la opinión del diario sobre el acontecimiento en sí o a llamar la atención del lector. A estas funciones expresivas y apelativas de no pocos titulares, se une la función poética, presente en las hipérboles y metáforas estudiadas, de modo que es prácticamente imposible encontrar un diario representativo, cuyo punto de vista sea neutral. Esto es así porque el terrorismo es un tema difícil de comprender, teóricamente complejo y con implicaciones emotivas. Parafraseando al escritor francés André Malraux, quizá, si los medios pudieran de veras llegar a comprenderlo, ya no podrían juzgar. Mucho nos tememos que eso sea imposible.

\section{Referencias bibliográficas}

BARTHES, Roland (1971): Elementos de Semiología. Madrid, Alberto Corazón Editor.

KAYSER, Jacques (1982): El diario francés. Barcelona, ATE.

MONTERO ESPINOSA, Pastora (1999): "Expresiones y contenidos del mensaje en periodismo escrito". Revista Latina de Comunicación Social, $\mathrm{n}^{\circ} 19$.

NÚÑEZ-ROMERO OLMO, Francisco (2009): La formación de las secciones de deportes en los diarios de información general españoles antes de 1936. Análisis hemerográfico estructural comparado. Tesis doctoral. Universidad Cardenal Herrera-CEU.

OLMO BARBERO, Jesús del y PARRATT FERNÁNDEZ, Sonia (2011): “Tipografía y color, un análisis de la prensa gratuita vs. la prensa de pago en España". Revista Latina de Comunicación Social, $\mathrm{n}^{\circ} 66$. 
SHOEMAKER, Pamela y REESE, Stephen (1996): Mediating the Message: Theories of Influences on Mass Media Content. New York, Longman.

TUCHMAN, Gaye (1978): Making News: A Study in the Construction of Reality. New York, The Free Press.

VERÓN, Eliseo et al. (1976): Lenguaje y comunicación social. Buenos Aires, Nueva Visión.

7. Anexos: imágenes de 15 de las portadas de diarios españoles más significativas

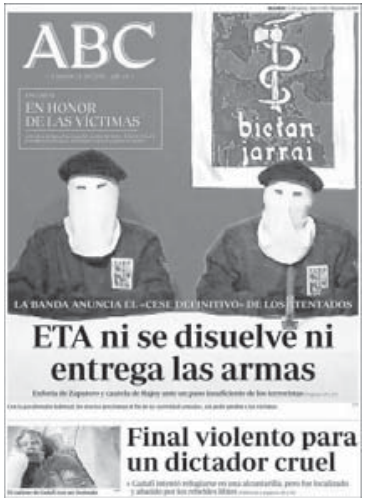

ABC (Madrid)

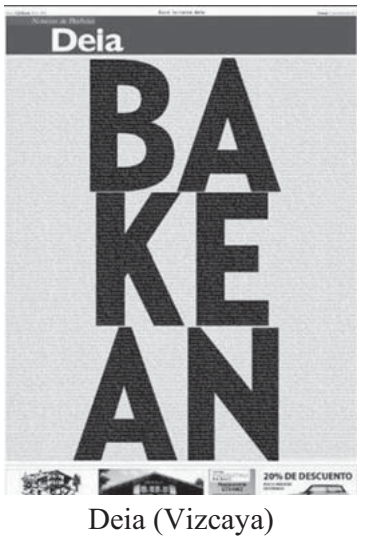

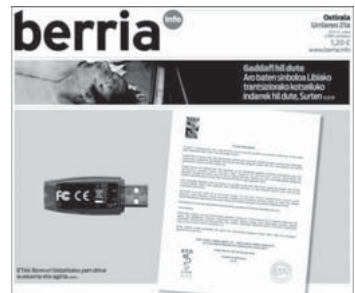
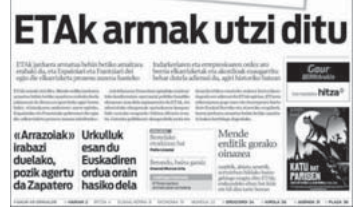

Berria (Guipúzcoa)

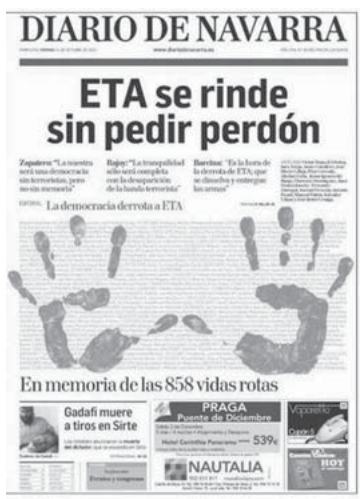

Diario de Navarra

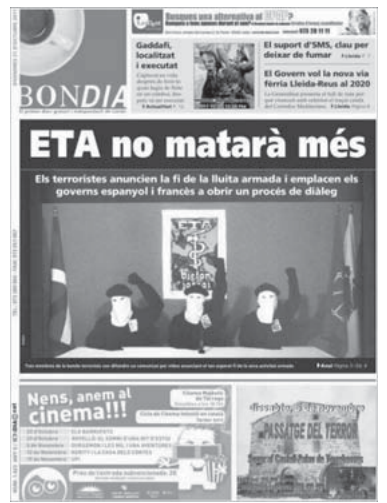

Bondia (Lérida)

\section{Diario}

FIN

틀

Diario de Noticias (Álava) 


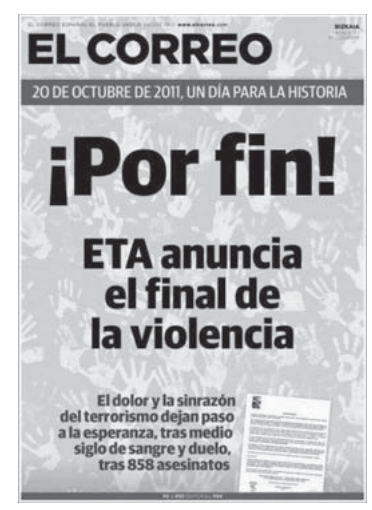

El Correo (Vizcaya)
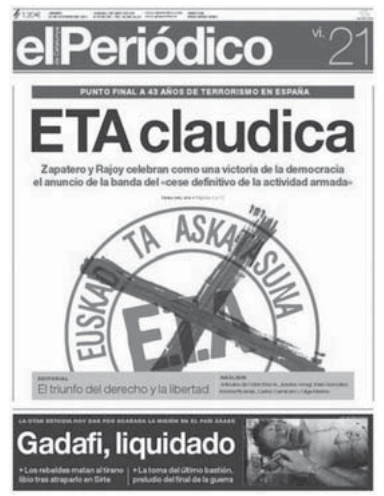

El Periódico (Cataluña)

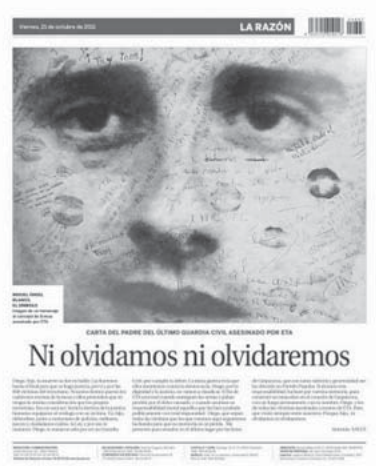

La Razón (Madrid)

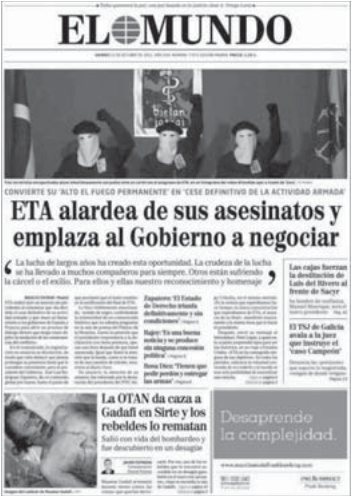

El Mundo (Madrid)

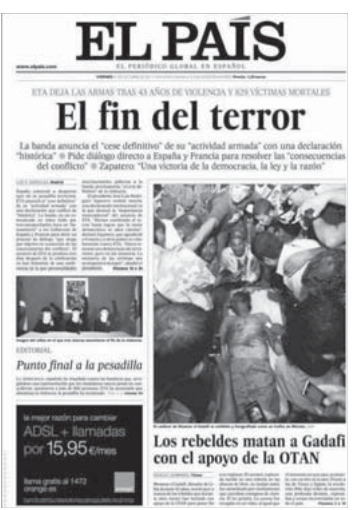

El País (Madrid)

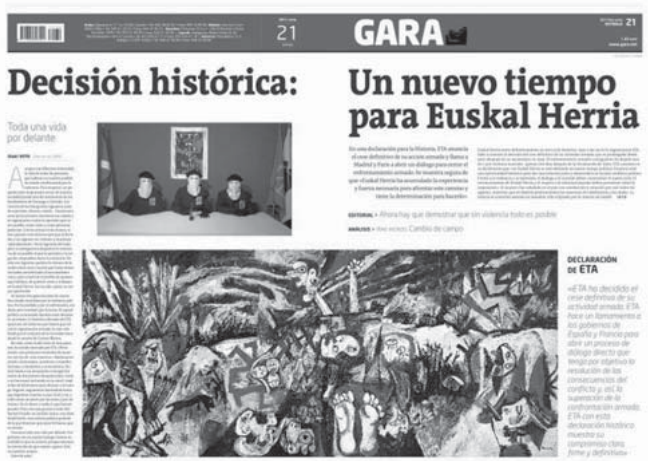

Gara (Guipúzcoa)

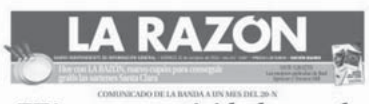

ETA cesa su actividad armada sin entregar las armas

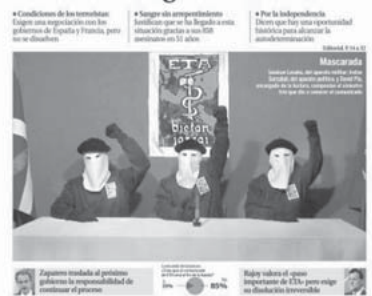

9픈
LAVANGUARDIA D. IA deja las

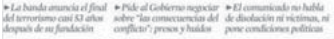

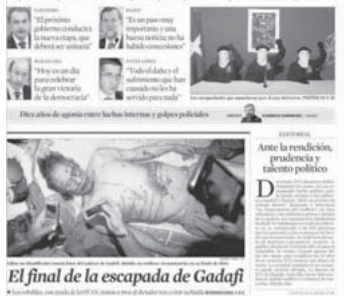

La Vanguardia (Barcelona) 


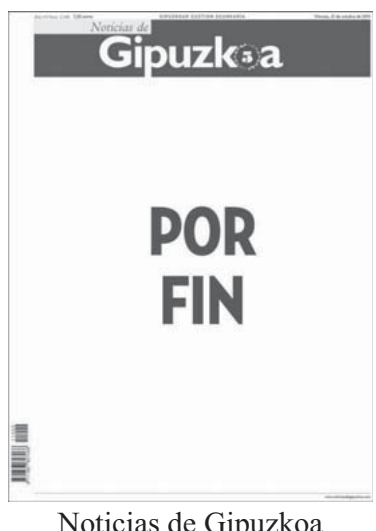

Noticias de Gipuzkoa

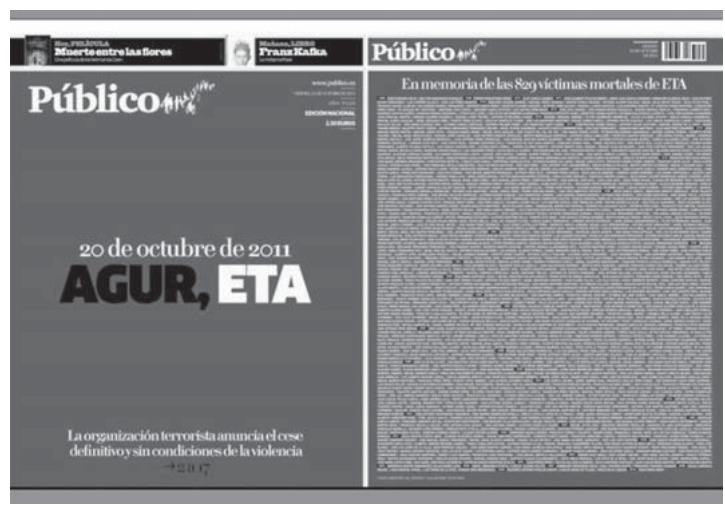

Público (Madrid) 